\title{
How to Translate an Action Verb Provide into Bahasa INDONESIA THROUGH THE NATURAL SEMANTIC METAlanguAGE
}

\author{
I Nengah Sudipa, I Gusti Bagus Narabhumi \\ Udayana University \\ nengahsudipa@unud.ac.id, bagusnarabhumi@gmail.com
}

\begin{abstract}
This study is aimed at mapping the meaning of action verb provide and its translation into Indonesian lexicons. The data sources of this study are two Colours Magazines of Garuda Indonesia, May 2017 and March 2018 editions. In collecting the data, this study applied the observation method and note taking technique. Those data were analyzed using Natural Semantic Metalanguage (NSM) approach proposed by Anna Wierzbicka (1996). Furthermore, the method of analyzing data was descriptive qualitative method. First, each of the data was analyzed to find its meaning configuration. Then, it was followed by the paraphrasing using semantic primitives to show the explication of each lexicon and be able to compare them. The results of this study show that the action verb provide is translated into five different Indonesian lexicons in the Colours Magazine. The verb and its translations have slight differences shown by the meaning configurations as well as explications. However, they could properly deliver the intended meaning for the Indonesian target readers regarding the sentences they are in.
\end{abstract}

Keywords: Natural Semantic Metalanguage, Bilingual Magazine, Translation, Action Verb

\section{INTRODUCTION}

The existence of bilingual magazines is flourishing in a demographic where several different communities with their own languages are interacting intensively. Among others, Colours Magazine published by Garuda Indonesia Airline as their in-flight magazine is one of the prominence bilingual magazines with contents in Indonesian and English language.

As a bilingual magazine with the purpose of entertaining and informing the target readers with short articles that has promotional values, there are several interesting lexicon in the class of verb, particularly action verb, regularly used in these articles. Givon (1984, in Suryasa 2016; 3) divides verbs into three broad classifications namely; state verb, process verb, and action verb. The action verb, particularly, comes from act by someone or something in which lexicon provide is included.

In the magazine, provide is translated into several different Indonesian lexicons. With the basic belief that every lexicon has its own distinctive characteristics (Jayantini, 2014; 35) or in other words, that there are no two words that have exactly the same meaning, this phenomenon becomes interesting and worth studied. In order to be able to analyze this phenomenon, the application of Natural Semantic Metalanguage approach proposed by Wierzbicka (1996) is appropriate.

The basis of NSM can describe the meaning conveyed in any language, as if from inside, while at the same time using sentences from our own language. Unlike various artificial language used for representation of meaning, the Natural Semantic Metalanguage carved out of Natural Language (Yanti, 2015). Goddard $(2008 ; 1)$ stated that the Natural Semantic Metalanguage (NSM) is a decompositional system of meaning representation based on empirically established universal semantic primes, i.e., simple indefinable meanings which appear to be present as identifiable word-meanings in all languages. In this study, the approach was applied by finding meaning configuration of each lexicon and paraphrasing them using the latest semantic primitives list with 64 primes in English exponents (Goddard, 2012; 3).

Finally, the purpose of this study is to map the meaning of provide as an action verb and the translations in Indonesian lexicons. Then, a comparison can be done and demonstrate how NSM approach can help us to understand a particular lexicon deeper. 


\section{MATERIALS AND METHODS}

In this study, the method includes four aspects, namely data source, method and technique of collecting data, method and technique of analyzing data and method and technique of presenting data. The data of this study are sentences found in Colours Magazine May 2017 and March 2018 editions. Colours Magazine is the In-flight Magazine of Garuda Indonesia Airline that has contents in English and Indonesian, as the airlines is an Indonesian airline that operates internationally. The magazine has mainly informative-descriptive articles that talk about Indonesian Archipelago besides several international destination and event articles. Informing about places, events, businesses, and products, there is a special lexicon regularly used in the text; the action verb provide. Furthermore, this English lexicon is translated into five different Indonesian lexicons that make it interesting to be analyzed using the NSM approach.

The method of collecting data used in this study was documentation method. In applying the method, the data source was carefully read and observed. Then, sentences with the occurrence of lexicon provide were noted. Next, those sentences that had different form of Indonesian lexicons to translate the action verb provide were listed to be further analyzed in the next section.

The method and technique of analyzing data was descriptive qualitative method in order to be able find the meaning configurations and explications of the action verb provide and the Indonesian translations. First, the previously listed data were analyzed to find the meaning configuration of each lexicon. Second, each lexicon was paraphrased using the semantic primitives in order to show the explication. Then, having the meaning configurations and explications, those lexicons were compared to find out how the target text lexicons differ and or similar to the source text lexicon.

Finally, the analyzed data were presented using the informal method. Informal method is the method in presenting data or analysis results in the form of ordinary words or descriptions and it is suitable for this study as a qualitative research.

\section{RESULTS AND DISCUSSION}

In the data source, the lexicon provide in the source text (ST) was translated into five different target text (TT) lexicons, namely; memberikan, menyediakan, menyuguhkan, and menyajikan, . Below are shown the meaning configurations and explications of lexicon provide and the translations according to the data of this study.

\subsection{PROVIDES AND MEMBERIKAN}

(3-1) Colours March, 2018 (Page 64)

\begin{tabular}{|l|l|}
\hline \multicolumn{1}{|c|}{ ST } & \multicolumn{1}{|c|}{ TT } \\
\hline $\begin{array}{l}\text { As well as maintaining a cultural tradition, Timorese } \\
\text { weaving provides economic sustainability and, most } \\
\text { noticeably, a source of pride for local communities. }\end{array}$ & $\begin{array}{l}\text { Dengan menjaga tradisi budaya, tenun Timor juga } \\
\text { memberikan kesinambungan ekonomi, dan yang paling } \\
\text { terlihat adalah menjadi sebuah kebanggaan } \\
\text { masyarakat lokal. }\end{array}$ \\
\hline
\end{tabular}

\subsubsection{MEANING CONFIGURATION}

Lexicon provides in the ST has the meaning of supplying something to someone; making them able to use, take, or enjoy the advantages from the supplied things. Meanwhile, the Indonesian translation memberikan means giving, delivering, and or allowing something to someone. However, the lexicon in ST has a good mood because the theme of this lexicon is most likely something beneficial or advantageous. In contrast, memberikan can deliver bad or good entities and therefore becomes a neutral lexicon in terms of mood.

Below are shown the explication of both lexicons where $\mathrm{X}$ is Timorese weaving and $\mathrm{Y}$ is economic sustainability and a source of pride. 


\subsubsection{THE EXPLICATION OF PROVIDES “MEMBERIKAN"}

$\mathrm{X}$ does something to $\mathrm{Y}$

This happens for some time

Because of this, Y can be someone's (local communities')

Because of this, people feel good

Because of this, people wants to do something (preserve) to $\mathrm{X}$

$\mathrm{X}$ does something like this

\subsubsection{THE EXPLICATION OF MEMBERIKAN "PROVIDES"}

$\mathrm{X}$ does something to $\mathrm{Y}$

This happens for a moment

Because of this, $Y$ moves

Because of this, people (local communities) can do something (receive) to $\mathrm{Y}$

Because of this, people feel good

Because of this, people wants to do something (preserve) to $\mathrm{X}$

$\mathrm{X}$ does something like this

From the explication, it can be concluded that generally, memberikan has a close meaning similarity to the ST lexicon. However, these explications also reveal the differences occurred in the translation of the lexicon; first in terms of time and second in term of process. The process of provides is done for some time meanwhile memberikan only happens in one moment. Besides, the action of moving that occurs in the TT lexicon does not exist in the explication of ST lexicon.

\subsection{PROVIDES AND MENYEDIAKAN}

\section{(3-2) Colours March, 2018 (Page 86)}

\begin{tabular}{|l|l|}
\hline \multicolumn{1}{|c|}{ SL } & \multicolumn{1}{|c|}{ TL } \\
\hline $\begin{array}{l}\text { Crowded into arches, along cobbled streets and under } \\
\text { Victorian and contemporary glass-roofed sheds, a } \\
\text { hundred and more stalls and shops provide unbeatable } \\
\text { fresh and cooked fare. }\end{array}$ & $\begin{array}{l}\text { Pasar ini dihiasi atap melengkung, jalanan berbatu dan } \\
\text { atap kaca bergaya Victoria dan kontemporer, dengan } \\
\text { ratusan kios dan toko yang menyediakan makanan } \\
\text { segar dan masakan yang tak ada duanya. }\end{array}$ \\
\hline
\end{tabular}

\subsubsection{MEANING CONFIGURATION}

In this data, lexicon provide is translated into menyediakan. Provide here has the meaning of making unbeatable fresh and cooked fare available in purpose to be enjoyed later. Meanwhile, menyediakan naturally has a very close meaning to the SL lexicon which is organizing something for later consumption. The entities, processes, and tools are also similar for both of the lexicon. Moreover, menyediakan has the same good mood as provide.

Below are shown the explication of both lexicons where $\mathrm{X}$ is stalls and shops and $\mathrm{Y}$ is food.

\subsubsection{THE EXPLICATION OF PROVIDES “MENYEDIAKAN"}

$\mathrm{X}$ does something to $\mathrm{Y}$

This happens for a long time

Because of this, there is $\mathrm{Y}$ in $\mathrm{X}$

Because of this, people (market visitors) can do something (buy, eat) to $\mathrm{Y}$ 
Because of this, people wants to move to $\mathrm{X}$

$\mathrm{X}$ wants this

$\mathrm{X}$ does something like this

\subsubsection{THE EXPLICATION OF MENYEDIAKAN “PROVIDE"}

$\mathrm{X}$ does something to $\mathrm{Y}$

This happens for a long time

Because of this, there is $\mathrm{Y}$ in $\mathrm{X}$

Because of this, $\mathrm{Y}$ is something (organized)

Because of this, people (market visitors) can do something (buy, eat) to Y

Because of this, people want to move to $\mathrm{X}$

$\mathrm{X}$ wants this

$\mathrm{X}$ does something like this

How both of provide and menyediakan show a nearly identical explication results re-emphasize how naturally close they are in meaning. The only difference is that menyediakan explicates how the theme is most likely become something (organized) in the process.

\subsection{Provides AND MeNYuguhKan}

Colours March, 2018 (Page 171)

\begin{tabular}{|l|l|}
\hline \multicolumn{1}{|c|}{ SL } & \multicolumn{1}{c|}{ TL } \\
\hline $\begin{array}{l}\text { Bali Safari \& Marine Park provides fun holiday } \\
\text { adventures in full measure - as it welcomes new tiger } \\
\text { cubs and an elephant calf }- \text { as well as its more enduring } \\
\text { mission of conservation. }\end{array}$ & $\begin{array}{l}\text { Bali Safari \& Marine Park menyuguhkan petualangan } \\
\text { liburan yang menyenangkan dengan hadirnya anak } \\
\text { macan dan anak gajah di tempat ini, serta petualangan } \\
\text { konservasi alam. }\end{array}$ \\
\hline
\end{tabular}

\subsubsection{MEANING CONFIGURATION}

In this case, the lexicon provides carries the meaning of giving the fun holiday adventures to the visitors of the park. Meanwhile the translation, menyuguhkan, has the meaning of serving and presenting the theme entities. Both of the lexicons result in the ability of Bali Safari \& Marine Park visitors to witness, experience, and enjoy an exciting holiday adventure. Furthermore, both also have the same good mood.

Below are shown the explication of both lexicons where $\mathrm{X}$ is Bali Safari \& Marine Park and $\mathrm{Y}$ is holiday adventures.

\subsubsection{THE EXPLICATION OF PROVIDES “MENYUGUHKAN"}

$\mathrm{X}$ does something to $\mathrm{Y}$

This happens for some time

Because of this, people can do something (experience, enjoy) to $\mathrm{Y}$

Because of this, people want to move to $\mathrm{X}$

$\mathrm{X}$ wants this

$\mathrm{X}$ does something like this

\subsubsection{EXPLICATION OF MENYUGUHKAN "PROVIDE"}

$\mathrm{X}$ does something to $\mathrm{Y}$ 
This happens for a some time

$\mathrm{X}$ does this because people in $\mathrm{X}$ are something (visitors)

Because of this, Y moves somewhere near people (visitors)

Because of this, people can do something (experience, enjoy) to $\mathrm{Y}$

Because of this, people want to move to $\mathrm{X}$

$\mathrm{X}$ wants this

$\mathrm{X}$ does something like this

Here, the explication of menyuguhkan is able to reveal in which feature it differs from the ST lexicon provide. Having a very similar meaning configuration, menyuguhkan actually has its own collocation with "visitors" (of houses or businesses). In contrast, the lexicon provides could deliver its theme to any recipients without the concerns on their status.

\subsection{Provide AND MenYaJIKAN}

Colours March, 2018 (Page 176)

\begin{tabular}{|l|l|}
\hline \multicolumn{1}{|c|}{ ST } & \multicolumn{1}{|c|}{ TT } \\
\hline $\begin{array}{l}\text { Hopefully, Colours will continue to innovate and } \\
\text { provide inspirational stories that focus on the wealth of } \\
\text { Indonesian culture and hospitality. }\end{array}$ & $\begin{array}{l}\text { Semoga Colours terus berinovasi dan menyajikan } \\
\text { cerita inspiratif dengan tetap mengedepankan kekayaan } \\
\text { budaya dan keramahtamahan bangsa. }\end{array}$ \\
\hline
\end{tabular}

\subsubsection{MEANING CONFIGURATION}

In data (3-4), provide is translated into menyajikan. Regarding the sentence, provide has the meaning of giving and supplying inspirational stories to the readers of the magazine. Meanwhile, menyajikan is referred to the act of presenting something to someone in a particular medium. The same with provide, menyajikan also has a good mood because the theme of this lexicon is most likely something beneficial or advantageous.

Below are shown the explication of both lexicons where $\mathrm{X}$ is Colours Magazine and $\mathrm{Y}$ is inspirational stories.

\subsubsection{THE EXPLICATION OF PROVIDES “MENYAJIKAN”}

$\mathrm{X}$ does something to $\mathrm{Y}$

This happens for a some time

Because of this, there is $\mathrm{Y}$ inside $\mathrm{X}$

Because of this, people (readers) can see $\mathrm{Y}$

Because of this, people want to do something (read) to $\mathrm{X}$

$\mathrm{X}$ wants this

$\mathrm{X}$ does something like this

\subsubsection{THE EXPLICATION OF MENYAJIKAN "PROVIDES"}

$\mathrm{X}$ does something to $\mathrm{Y}$

This happens for a some time

Because of this, there is $\mathrm{Y}$ inside $\mathrm{X}$

Because of this, $\mathrm{X}$ is something (organized, well placed, easily consumed)

Because of this, people (readers) can see $\mathrm{Y}$ 
Because of this, people wants to do something (read) to $\mathrm{X}$

$\mathrm{X}$ wants this

$\mathrm{X}$ does something like this

Once again, these explications successfully point out how two lexicons with a very close meaning to each other still have feature differences. More precisely, the semantic prime in the specification category shows that TT lexicon menyajikan results in organized theme meanwhile ST lexicon provides does not indicates such thing.

\subsection{PROVIDES AND MENGHADIRKAN}

\section{(3-5) Colours May, 2017 (Page 57)}

\begin{tabular}{|l|l|}
\hline \multicolumn{1}{|c|}{ ST } & \multicolumn{1}{|c|}{ TT } \\
\hline $\begin{array}{l}\text { The newly designed Bulgari boutique provides the } \\
\text { best of both worlds, offering the brand's iconic } \\
\text { collections in an exquisite retail setting inspired by } \\
\text { traditional Balinese forms and refined Italian elegance. }\end{array}$ & $\begin{array}{l}\text { Bulgari Boutique yang baru, menghadirkan deretan } \\
\text { koleksi ikonis Bulgari dalam keindahan atmosfer yang } \\
\text { terinspirasi bentuk-bentuk tradisional Bali dan } \\
\text { keanggunan Italia. }\end{array}$ \\
\hline
\end{tabular}

\subsubsection{MEANING CONFIGURATION}

In this data, provides that carries the meaning of presenting and supplying something valuable is translated into Indonesian lexicon menghadirkan. Menghadirkan in this case has the meaning of presenting or making something present in a certain place or medium in order to make them well-known to the target audiences. However, lexicon menghadirkan has a neutral mood since it could deliver bad or good entities.

Below are shown the explication of both lexicons where $\mathrm{X}$ is Bulgari Boutique and $\mathrm{Y}$ is apparel collections.

\subsubsection{THE EXPLICATION OF PROVIDES “MENGHADIRKAN"}

$\mathrm{X}$ does something to $\mathrm{Y}$

This happens for some time

Because of this, $\mathrm{Y}$ is something (available)

Because of this, people can do something to Y (see, touch, try, buy)

$\mathrm{X}$ wants this

$\mathrm{X}$ does something like this

\subsubsection{THE EXPLICATION OF MENGHADIRKAN "PROVIDES"}

$\mathrm{X}$ does something to $\mathrm{Y}$

Because of this, $\mathrm{Y}$ moves inside $\mathrm{X}$

This happens for a moment

After this, there is $\mathrm{Y}$ inside $\mathrm{X}$

After this, people (consumers) can do something to Y (see, touch, try, buy)

$\mathrm{X}$ wants this

$\mathrm{X}$ does something like this

This explication show that the translation of lexicon provide into menghadirkan has several differences. Similar with the case in data (3-1), provide and menghadirkan here differ in the semantic 
prime category of time. Furthermore, lexicon provides indicates its theme specification which is "available", meanwhile lexicon menghadirkan stresses more on what experience its theme undergone which is "moving". However, once again the general explication result shows that menghadirkan is equivalent enough to be considered as an appropriate translation for lexicon provide in data (3-5).

\section{CONCLUSION}

According to the discussions, it can be concluded that the action verb provide has the meaning of supplying something to someone and is translated into five different Indonesian lexicons, namely; memberikan, menyediakan, menyuguhkan, menyajikan, and menghadirkan. Through the meaning configuration, it is shown that the ST lexicon provide has a positive or good mood. Yet, only menyediakan, menyuguhkan and menyajikan have the same mood; the other two, memberikan and menghadirkan, have neutral mood instead. The explication comparison procedures also point out the slight differences of ST and TT lexicons regarding the sentences they are in. However, those differences do not significantly affect the equivalency of TT toward ST lexicons since they could properly deliver the intended meaning of provide for the Indonesian target readers.

\section{REFERENCES}

Goddard, Cliff. (2008). 1. Natural Semantic Metalanguage: The state of the art. 1-34. $10.1075 /$ slcs.102.05god.

Goddard , C. 2015. The Oxford Handbook of Linguistic Analysis (2 ed.). http://www.oxfordhandbooks.com; Online Publication.

Jayantini, S. R. (2014). The Medical Concept of Damage and Its Indonesian Equivalent Cedera: A Natural Semantic Metalanguage Approach. Lingual: Journal of Language and Culture. Denpasar: Udayana University.

Suryasa, I. W. (2016). Ngalap in Balinese: a Natural Semantic Metalanguage Approach. Lingual: Journal of Language and Culture. (https://ojs.unud.ac.id/index.php/ language/article/view/21155>. Date accessed: 2 march. 2018.)

Wierzbicka, Anna. 1996. Semantics: Primes and universals. Oxford: Oxford University Press.

Yanti, M. A. (2015). Grade Mapping of Order Group Speech Act Verb in The Motivation Book Entitled Opening The Door of Your Heard. and Its Translation (Thesis). Denpasar: Udayana University (data source)

Garuda Indonesia. 2017. Colours Magazine May 2017. www.garuda-indonesia.com; Online Publication.

Garuda Indonesia. 2018. Colours Magazine March 2018. www.garuda-indonesia.com; Online Publication. 